\title{
Gender Mainstreaming in Arabic Literature
}

\author{
Awaliah Musgamy $^{1^{*}}$, Muhammad Rusydi ${ }^{2}$, Kurniati $^{3}$ \\ ${ }^{1}$ Arabic Education Study Program Universitas Islam Negeri Alauddin Makassar, Indonesia \\ ${ }^{2}$ Arabic Education Study Program Institut Agama Islam Negeri Bone, Indonesia \\ ${ }^{3}$ Constitutional Law Study Program Universitas Islam Negeri Alauddin Makassar, Indonesia
}

\section{Article History:}

Received : May 29, 2020

Revised : June 19, 2020

Accepted : July 20, 2020

Published : December 01, 2020

Keywords:

Arabic; Feminist; Gender; Literature Critic

*Correspondence Address: awaliah.musgamy@uinalauddin.ac.id

\begin{abstract}
Arabic literature is a means of gender mainstreaming which is very rich in gender issues. This is based on the social fact that Arab society in its historical footsteps has a stereotype as a community that is very thick with its patriarchal culture. Consequently, the social condition which is less responsive to gender influences the birth of Arabic literary works in various types in which gender issues such as marginalization of women, subordination of women to men, violence, negative stereotypes, and others. This article is qualitative research by using feminist Arabic literary criticism as a perspective, gender mainstreaming in Arabic literature is carried out by tracing the gender issues that exist in Arabic literature in its various forms. Through feminist Arabic literary criticism, various theories of feminist literary criticism consisting of ideological criticism, gynocritical criticism, socialist criticism, psychoanalytic criticism, ethnic criticism, and lesbian criticism, are applied in transforming and reconstructing gender-responsive relations between men and women.
\end{abstract}

\section{Introduction}

Gender Issue $^{1}$ is an issue that is full of struggles for the basic rights of women which have been monopolized by men in the framework of a patriarchal life. Gender is a gateway of hope for the realization of a social relationship between men and women who are attached within the frame of gender justice. ${ }^{2}$ Responding to this, Mansour Fakih stated that gender issues are a crucial issue to be raised in complementing various issues

\footnotetext{
${ }^{1}$ Gender issues (gender identity) are differentiated from one another in important documents such as the American Psychological Association (APA). Douglas Knutson et al., "An Exploration of Gender from The Perspective of Cisgender Male Drag Queens," Journal of Gender Studies 29, no. 3 (April 2, 2020): 325-337.

${ }^{2}$ It is necessary to explore more about the influence of stereotypes that is well-constructed and tending to have on people's perceptions of social gender roles and how these perceptions construct the social fibers of the sphere of relationships between men and women. It is intended that kind of understanding will make the society more aware of the dangers of stereotypical associations in society for men and women Maria Elena Aramendia-Muneta, Cristina Olarte-Pascual, and Leonidas Hatzithomas, "Gender Stereotypes in Original Digital Video Advertising," Journal of Gender Studies 29, no. 4 (May 18, 2020): 403-419.
} 
of social injustice that have existed before. In the class analysis developed by Karl Marx as a form of resistance to the capitalist system, for example, the issue of gender can be a complement to the analysis because it is supported by real social facts. Likewise, the analysis of ideological and cultural hegemony developed by Antonio Gramsci will only lead to a weak analysis without any support for strengthening the gender issues. ${ }^{3}$ It shows that there is a need of gender mainstreaming in various scientific fields as an effort to transform gender justice in the transformation of science as a platform for the realization of social life with all its dynamics.

In terms of gender mainstreaming in various scientific fields ${ }^{4}$, Arabic literature is a study that has a lot of various concepts of feminist literary criticism. This refers to the position of literature as a medium for conveying human aspirations for various social realities that surround it, including gender injustice. In historical facts, Arab society has a stereotype $^{5}$ as a community that tends to keep the patriarchal culture ${ }^{6}$ in which women are in a vertical-coordinative position compared to men. ${ }^{7}$ Gartung said this patriarchal culture is as the cultural violence ${ }^{8}$, that consider the direct and structural violence is something common.

Moreover, In jahiliyyah era the birth of a daughter was sometimes considered a disgrace to their family or tribe at that time. ${ }^{9}$ This is told in QS. an-Nahl / 16: 58 "And when one of them is informed of [the birth of] a female, his face becomes dark, and he

\footnotetext{
${ }^{3}$ Mansour Fakih, Analisis gender dan transformasi sosial (Pustaka Pelajar, 2013), 4.

${ }^{4}$ Elomäki and Sandberg also alluded on gender mainstreaming in various scientific fields, one of which is a feminist perspective on economics in the transformation of a country. They said that feminism and gender issues can be used to study economics. Anna Elomäki and Paula Koskinen Sandberg, "Feminist Perspectives on the Economy within Transforming Nordic Welfare States," NORA - Nordic Journal of Feminist and Gender Research 28, no. 2 (April 2, 2020): 81-85.

${ }^{5}$ Gender stereotypes have been studied since the 1970s across cultures and countries according to Courtney and Lockeretz in Aramendia-Muneta, Olarte-Pascual, and Hatzithomas, "Gender Stereotypes in Original Digital Video Advertising."

${ }^{6}$ Vered explained in his research that the perception of patriarchy can grow in the society that cause many case, not only men but women also take part in the conception of patriarchy. Vered Ne'Eman-Haviv, "Attitudes of Arab Israeli Students towards Honour Killings," Journal of Gender Studies (June 2, 2020): 111.

${ }^{7}$ In line with Alawiyah's statement, the phenomenon of social injustice such as the marginalization of women, the placement of women in subordination is detrimental to women who are considered to be in a vertical-coordinative position when connected with men on its axis. Awaliyah Musgamy, "Menakar Batas Kesetaraan Gender Poligami Dalam Pp. No. 45 Tahun 1990 Tentang Izin Perkawinan Dan Perceraian Bagi PNS," Al Daulah: Jurnal Hukum Pidana dan Ketatanegaraan 6, no. 2 (June 25, 2018): 395-404.

${ }^{8}$ Johan Gartung, "Local Authorities as Peace Factors/Actors/ Workers," Journal of World-Systems Research (November 26, 2000): 860-872.

9 Amin Nasir, "Bahasa Arab Era Klasik Dan Modern (Tinjauan Pembelajaran Teoritis)," Arabia 6, no. 1 (2014), accessed June 27, 2020, https://journal.iainkudus.ac.id/index.php/Arabia/article/view/1393.
} 
suppresses grief ",10 This social phenomenon lasted quite a long time, so that many literary works recorded this, from defending women to those who incriminated them. The meeting of the two poles of Arabic literary works, between sympathy and antipathy, between protagonists and antagonists, in addressing gender issues so as to present a massive gender dialectical process.

One of the practical implications of the phenomenon above is the birth of feminist literary criticism, which is a discipline in literary criticism that exists as a response to the development of feminist studies. ${ }^{11}$ As a development of feminist literary criticism, feminist Arabic literary criticism was born which is a gender study perspective that has an interesting scientific framework to study because it contains a gender dialectic between text and reality. By not denying the existence of a gender dialectic between text and reality in feminist literary criticism in various other parts of the world, but in the context of Arab society with all of the social realities which still tend to be influenced by the patriarchal culture, feminist Arabic literary criticism has its own advantages. One of the platforms for developing feminist Arabic literary criticism is Arabic literature itself in its various forms, both imaginative and non-imaginative, which are widely studied in the development of science, both theoretically and practically. ${ }^{12}$

The reality above is an opportunity to make Arabic literature in its various forms a forum for gender mainstreaming through feminist Arabic literary criticism. The need for feminist studies was put forward by Shulamit Reinharz who argued that the feminist method, such as the one in feminist literary criticism, is a forum for knowledge in understanding women both individually and communally. ${ }^{13}$ In this process, women can be understood holistically from the aspects of their relationships with other women, their relationships with men, and their social contact in the locus of race, gender, class, age, and the way of life that shapes their life patterns. ${ }^{14}$ Referring to this, the author raises the title "Pengarusutamaan Gender dalam Sastra Arab: Perspektif Kritik Sastra Arab

\footnotetext{
${ }^{10}$ QS. al-Nahl/16:58

11 Sugihastuti and Suharto, Kritik Sastra Feminis: Teori Dan Aplikasinya (Yogyakarta: Pustaka Pelajar, 2002), 61.

${ }^{12}$ Aning Ayu Kusumawati, "Feminisme Islam dalam Novel Abidah El Khalieqy," THAQAFIYYAT: Jurnal Bahasa, Peradaban dan Informasi Islam 14, no. 2 (2013): 115-137.

${ }^{13}$ Michelle Hartman, "'Zahra's Uncle, or Where Are Men in Women's War Stories?,"” Journal of Arabic Literature 51, no. 1-2 (April 6, 2020): 83-107.

${ }^{14}$ Shulamit Reinharz, Metode-Metode Feminis Dalam Penelitian Sosial, Terj. Lisabona Dan J. Bambang Agung (Jakarta: Women Research Institute, 2005), 214.
} 
Feminis" (Gender Mainstreaming in Arabic Literature: The Perspective of Feminist Arabic Literary Criticism).

\section{Method}

This study used a qualitative approach by linking literature findings to previous studies. The qualitative approach of the researcher is used to view gender studies in Arabic literature with the glasses of feminist Arabic literary criticism. In literary criticism, content analysis is used as a technique to see the extent of the relationship between text and context. The scheme in this research is as illustrated below:

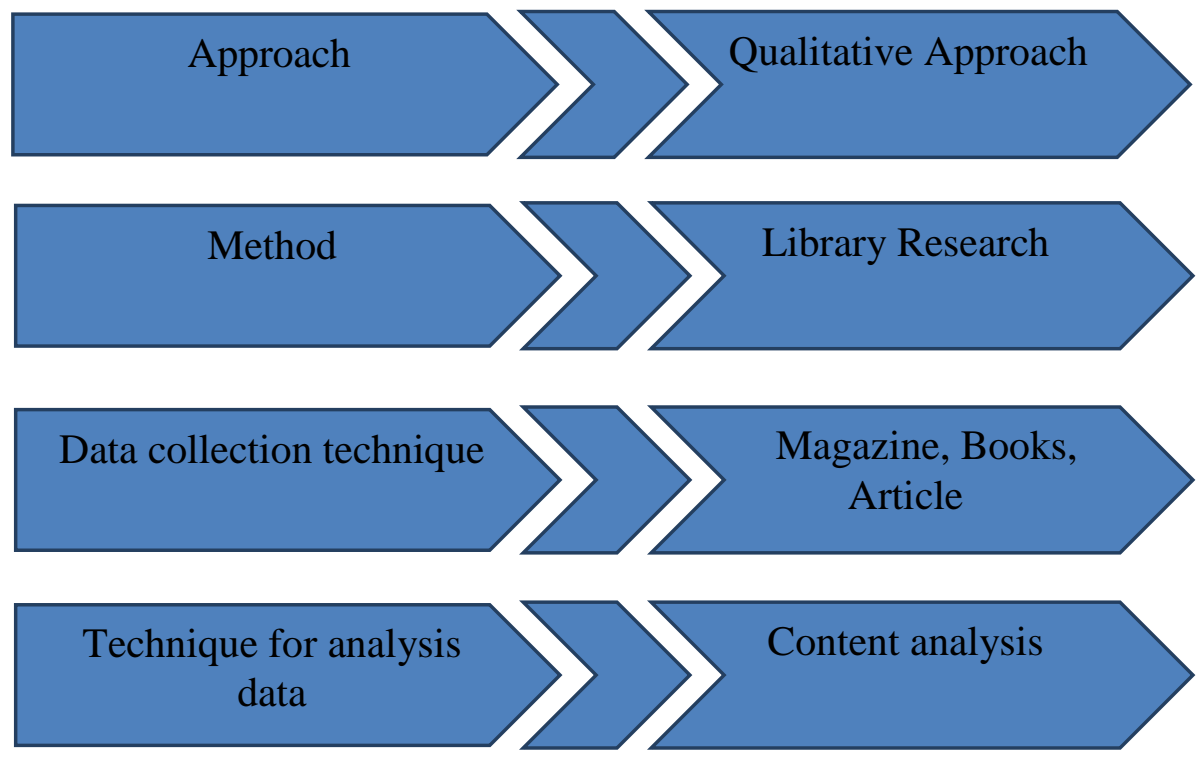

Figure 1. Method

\section{Result and Discussion}

Women, in their historical framework, cannot be separated from various phenomena of social insecurity on their basic rights as human beings. The patriarchal culture which has a very strong influence in various parts of the world has made women a commodity that is considered as goods and can be bought and sold so that women's rights to be actively involved in various social activities are severely restricted and even eliminated. ${ }^{15}$ These stereotypes then make the birth of a girl an unexpected birth. Similar to what happened to the Arab ignorance when they got a daughter, they became very angry as enshrined in QS. An-Nahl / 16: 58. So did in Rome, as described by Ismail

${ }^{15}$ Warni Tune Sumar, "Implementasi Kesetaraan Gender dalam Bidang Pendidikan," MUSAWA 7, no. 1 (June 2015): 158-182. 
Adam Patel, when the birth process becomes something exciting, considering that the birth of a son or daughter has implications for the dignity of the family. The birth of a son was a matter of pride while the birth of a girl was seen as a disgrace, so that if the child was a girl then the custom allowed the father to kill her. ${ }^{16}$

The lack of respect for women has become a kind of immanent stereotype of their inability to carry out various activities. There is a kind of stereotype that always develops that women are men companions in life. This is certainly different from what Muhammad Rusydi expressed that gender is a social construction that is agreed upon by a community while sex refers to more to biological identity itself as a provision immanent to human physical reality. ${ }^{17}$

Basically, it is common enough to say that women are men's companions in life as long as they can form a relationship in a gender-equitable partnership. The fact is that the position of women as male companions has been understood as an attempt for women in the domestic space of the household while men have wider access in terms of career development outside the domestic space. ${ }^{18}$ Men are seen as more capable of taking care of themselves if they work outside while women who work outside are very vulnerable to various acts of harassment so they should be left in the domestic space of the household. ${ }^{19}$ Moreover, these stereotypes seem to have hypnotized policy makers at the government level not to accommodate the provision of various public facilities, such as gender responsive ones, because from the outset they understood that the number of women who worked outside was insignificant. These various forms of gender inequality have led to the emergence of a feminist movement called gender mainstreaming. This is also illustrated in the writings of Iḥsān 'Abd al-Quddūs, which form the popular idea of love, frustration with postcolonial reality, resulting in the emergence of deviance (lesbian love), issues of women's mobility and liberation. ${ }^{20}$

\footnotetext{
${ }^{16}$ Ismail Adam Patel, Perempuan, Feminisme Dan Islam, Terj. Abu Faiz (Bogor: Pustaka Thariqul Izzah, 2005), 2.

${ }^{17}$ Muhammad Rusydi, "Esoterisme Pemikiran Gender Nasaruddin Umar," AN-NISA : Jurnal Studi Gender dan Anak 12, no. 2 (March 10, 2020): 711.

${ }^{18}$ Men have a role to defend and maintain his family, also be responsible for obtaining all the necessities of his family. Wardah Nuroniyah, "Perempuan Arabia Dalam Lingkaran Perkawinan Di Era Pra-Islam," Yinyang: Jurnal Studi Islam Gender dan Anak 14, no. 2 (December 10, 2019): 175-200.

${ }^{19}$ Deffi Syahfitri Ritonga, "Kajian Gender Pada Novel Karya Nawal El Saadawi Dan Sutan Takdir Alisjahbana," Arabiyat: Jurnal Pendidikan Bahasa Arab dan Kebahasaaraban 3, no. 1 (June 28, 2016): 13-31.

${ }^{20}$ Hanan Hammad, "In the Shadows of the Middle East's Wars, Oil, and Peace: The Construction of Female Desires and Lesbianism in Middlebrow Egyptian Literature," Journal of Arabic Literature 50, no. 2 (July 15, 2019): 148-172.

249 | Jurnal Al Bayan: Jurnal Jurusan Pendidikan Bahasa Arab, 12 (2): 245-262 (2020)
} 
Gender mainstreaming, in its implementation, must be able to transform gender values from traditional to egalitarian, from a role that simply transmits the dominant values that live in society in the locus of patriarchal culture to a role that transforms values that promote gender equality and justice. ${ }^{21}$ Considering that a patriarchal culture has long existed in people's life and has even been able to influence strategic government policies, either directly or indirectly, gender mainstreaming, in its application, must be carried out with structured steps including departing from an in-depth social analysis.

In an effort to expand the scope of gender mainstreaming as a structured step in internalizing gender responsive values in various areas of human life that are prone to the proliferation of patriarchal culture, their application must be developed in a wider contest including the internationalization of the concept of gender mainstreaming in literary studies, including Arabic literature.

\section{Arabic Literature and Feminist Critique of Arabic Literature: From Text to Reality}

Literature is a way of human to understand the world around them imaginatively. ${ }^{22}$ Consequently, everything written can be understood as part of literature because it can provide an imaginative illustration of a fact or idea immanent to writing. ${ }^{23}$ The definition expressed is still too general because it is still tied to the etymological meaning of the origin of the literary word ${ }^{24}$, which in this case is the word "literature". This phenomenon is commonly found in everyday life where the word which has been absorbed in Indonesian into the word "literatur" is usually interpreted as a document which is something written. In this sense, Jacob Sumardjo and Saini then described the various types of literature in a structured manner as follows: ${ }^{25}$

21 Oktiana Jatiningsih, "Pengarusutamaan Gender (PUG) Dalam Pendidikan Sebagai Strategi Pendidikan Karakter Bagi Calon Guru Di Lembaga Pendidikan Guru Dan Tenaga Kependidikan," Prosiding Seminar Nasional Lembaga Pengembangan, Pembelajaran, dan Penjaminan Mutu (November 5, 2016): 99.

${ }^{22}$ Akhmad Muzakki, “Karya Sastra: Mimesis, Realitas Atau Mitos?," LiNGUA: Jurnal Ilmu Bahasa dan Sastra 2, no. 1 (October 13, 2011): 26-44.

${ }^{23}$ Edward Harrell Jones, Outlines of Literature; Short Stories, Novels, and Poems (New York: Macmillan, 1968), 1.

${ }^{24}$ Literary work is a reflection of the whole life of the Arabs during the pre-Islamic era. Haeruddin Almandary, "Karakteristik Sastra Arab pada Masa Pra-Islam," Nady Al-Adab 13, no. 1 (January 23, 2018): 35-50. 19.

${ }^{25}$ Jacob Sumarjo and Saini, Apresiasi Kesusasteraan (Jakarta: Gramedia Pustaka Utama, 1997), 18- 
Table 1. Kind of Literature

\begin{tabular}{|c|c|c|c|c|}
\hline \multicolumn{5}{|c|}{ Literature } \\
\hline Non-Imaginative Literature & \multicolumn{4}{|c|}{ Imaginative Literature } \\
\hline & Poem & \multicolumn{3}{|c|}{ Prose } \\
\hline & \multirow{3}{*}{$\begin{array}{c}\text { Epic, } \\
\text { lyric, } \\
\text { and } \\
\text { dramatic }\end{array}$} & Fiction & \multicolumn{2}{|c|}{ Drama } \\
\hline & & $\begin{array}{l}\text { Novel, Short } \\
\text { story, and } \\
\text { novelette }\end{array}$ & Prose Drama & $\begin{array}{l}\text { Poem } \\
\text { Drama }\end{array}$ \\
\hline & & $\begin{array}{l}\text { Novel, Short } \\
\text { story, and } \\
\text { novelette }\end{array}$ & \multicolumn{2}{|c|}{$\begin{array}{l}\text { Comedy, Tragedy, } \\
\text { Melodrama, and Tragic- } \\
\text { comedy }\end{array}$} \\
\hline
\end{tabular}

In a more specific sense, it is not sufficient for literature to be understood only by referring to the etymological meaning, because the fact is that not all written documents can be understood as literary works. ${ }^{26}$ There is even a tendency to understand literature in imaginative literature while non-imaginative literature such as essays, criticisms, biographies, autobiographies, history, memoirs, diaries, and letters, although still classified as literature, its literary value is not comparable to imaginative literature. Perhaps this is also what drives Edward H. Jones in his definition of literature above to be associated with the way humans use to understand the world around them imaginatively. Responding to this, Saryono argued that literature must be understood as a living person who always actively interacts with the dynamics of social reality that surrounds it, such as politics, economy and culture. Literature has the ability to guide humans to truth because literature is written with full honesty, sincerity, wisdom, and human conscience. ${ }^{27}$

Some of the immanent characteristics to literary works are as follows, 1) literature is not a practical communication where the implied meaning is more dominant than the express meaning, 2) literary works are creative works, not merely imitative ${ }^{28}, 3$ ) literary works are works imaginative and not a representation of reality, 4) literary works are autonomous works, 5) literary works are coherent works where all elements have meaning, including the point, 6) the conventions of a society determine which works can be called literature and which are not. ,7) and literature is not just a written or created

\footnotetext{
${ }^{26}$ Muzakki, "KARYA SASTRA.”

${ }^{27}$ Saryono, Pengantar Apresiasi Sastra (Malang: Universitas Negeri malang, 2009), 16-17.

${ }^{28}$ Muzakki, "KARYA SASTRA.”
} 
language, or just a language game, but it is a language that contains more meaning by offering values that can enrich spiritually and improve the quality of life. ${ }^{29}$

In relation to Arabic literature which is generally known as al-Adab al-'Arabi, Arabic literature can be said to be a beautiful and clear work which is made with the aim of touching the souls of those who recite or listen both in verse and in prose. ${ }^{30}$ As what was stated by Al-Ziyat Ahmad Husain shows that Arabic literature is more commonly found in two types of literature in general, in this case poetry and prose. If this is confirmed by the views of Jacob Sumardjo and Saini who have divided the types of literature into two main parts, namely non-imaginative literature and imaginative literature, Arabic literature is more commonly found in imaginative literary, which in this case is poetry in the form of verses, and prose in the form of stories or novels. The question then is, did other types of literature not exist in Arabic literature when Al-Ziyat Ahmad Husain specified the Arabic literature to those two types of literature? The answer is that Arabic literature continues to develop, so that it is possible to find various types of literature in Arabic literature.

There is a limitation on the type of Arabic literature on two types of literature, namely poetry in the form of poetry and prose in the form of a story or novel, which refers more to the object of literary study in the early days of the development of the literary criticism tradition, which at that time the material objects were not far from two types literature.

In its historical framework, the ignorant Arabs were a very talented nation in terms of literature so that from them emerged famous literary experts including Umru al-Qais, al-Nabighah al-Dzubyani, A'sya, Harith bin Hillizah al-Yaskari, Antarah al- Absi, Zuhair bin Abi Sulma, Lubaid bin Rabi'ah, and others. These Arabic literary scholars used to express their literary works in the Ukaz market as a form of immanent pride for themselves or their tribe. Arabic literary works that were considered superior were then appreciated by hanging on the walls of the Ka'bah. ${ }^{31}$ This historical fact shows that Arabic literature has undergone a very massive development since pre-Islamic era which is usually labeled as the period of ignorance (al-Fatrah al-Jahiliyah) so that many people

${ }^{29}$ Akhmad Muzakki, Kesusastraan Arab Pengantar Teori Dan Terapan (Jakarta: ANS, 1995), 3536.

${ }^{30}$ Al-Ziyat Ahmad Husain Husain, Tarikh Al-Adab al-Arabi (Kairo: Dar al-Ma'rifah, 1975), 32.

31 Abd. al-Aziz bin Muhammad al-Faishal, Al-Adab al-'Arabi Wa Tarikhuhu (Riyadh: : alMamlakah al-`Arabiyah al-Su'udiyyah, 1405), 75. 
understand that the labeling of this period as a period of ignorance is more on some aspects that are due to the low intellectual quality of Arab society in that period, but the contemptibly characters itself that have become their stereotypes such as the habit of having war for various profane purposes, the lack of respect for women's rights, the lack of security guarantees of personal rights or groups that should be protected, and others.

The development of Arabic literature has gone through a long historical phase ${ }^{32}$ with various social dynamics surrounding it. ${ }^{33}$ To decribe these phases, Ahmad Iskandari and Mustafa Inani provided the details of several phases, starting from the Jahiliyah phase which lasted approximately 150 years from 475 AD to 622 AD. This Jahiliyah phase ended with the arrival of Islam. ${ }^{34}$ The early phase of Islam lasted from 622 AD to $750 \mathrm{AD}$. This early phase of Islam took place from the very beginning of the arrival of Islam where the Prophet (PBUH) struggled to spread the word of Islam until the end of the Umayyad dynasty. ${ }^{35}$ The Abbasid dynasty lasted from $750 \mathrm{AD}$ to $1258 \mathrm{AD}$ and ended with the fall of Baghdad into the hands of Tatars. ${ }^{36}$ The phase of the Turkish Daulah lasted from 1258 AD to 1797 AD. This phase also includes the Mamalik dynasty in Egypt and Syria, the Daulah that was abandoned by the Tatars in Asia, and the Ottoman Empire. ${ }^{37}$ The modern revival phase lasted from 1798 AD until now. This phase is marked by the reign of Muhammad Ali in Egypt. ${ }^{38}$

The emergence of feminist Arabic literary criticism cannot be separated from the feminist movement which fights for more proportional roles of women, both in the domestic sphere and in the public sphere. As a consequence, the understanding related to the objectives of feminist Arabic literary criticism in particular cannot be separated from the objectives of feminist literary criticism in general, which in terms of three, namely feminist literary criticism is an alternative medium in studying and examining the implied or implied meaning of a literary text. Then feminist literary criticism is a

\footnotetext{
${ }^{32}$ Sitti Maryam, "Historisitas Aliran Neo-Klasik Dalam Kesusastraan Arab," Al-Irfan : Journal of Arabic Literature and Islamic Studies 2, no. 1 (March 30, 2019): 121-141.

${ }^{33}$ Abd Aziz and M. Imam Sofyan Yahya, "Kritik Intrinsikalitas dan Ekstrinsikalitas Sastra Modern dalam Kajian Sastra Arab Modern,” Mumtaz: Jurnal Studi Al-Quran dan Keislaman 3, no. 1 (October 21, 2019): 23-36.

${ }^{34}$ Almandary, "Karakteristik Sastra Arab pada Masa Pra-Islam."

${ }^{35}$ Ratna Ajeng Tedjomukti and Agung Sasongko, "Sastra Arab dari Berbagai Zaman," Republika Online, last modified August 15, 2017, accessed June 27, 2020, https://republika.co.id/share/ouoyap313.

${ }^{36}$ Ibid.

${ }^{37}$ Maryam, "Historisitas Aliran Neo-Klasik Dalam Kesusastraan Arab."

${ }^{38}$ Ahmad Iskandari and Mustafa Inani, Al-Wasith Fi al-Adab al- 'Arabi Wa Tarikhihi (Kairo: Dar alMa'arif, 1916), 10.
} 
medium for reinterpreting various types of literary works produced over a long period of time and even in past centuries. With feminist literary criticism, various literary works can be understood, interpreted, and assessed by referring to the stories presented by female writers. Feminist literary criticism is a medium for questioning the validity and completeness of traditional ways of assessing to be more accommodating to feminist values. The old methods were deemed inadequate because they did not concern to female writers, nor did they consider female figure. ${ }^{39}$

Feminist Arabic literary criticism is an attempt to transform text into reality. When the spirit of the feminist movement developed by the West wants to be applied in the Islamic world, Hasan Hanafi has provided a platform for how to develop it, one of which is how Muslims are able to transform text into reality. This has been hinted at in the Occidentalism initiated by Hasan Hanafi in relation to our attitude towards the old traditions. ${ }^{40}$ Various Arabic literary works are Islamic scientific traditions which should not only be recorded in the pages of literary works in the form of manuscripts, books, or else, but must be a dialectic text with reality including giving effect to them.

In this effort, feminist Arabic literary criticism can be directed at several theoretical frameworks for the application of feminist literary criticism, which in this case is an ideological criticism that involves women as readers. The main focus of this theory is the stereotypes of women depicted in various literary works. This theory of criticism is also used to further examine misconceptions related to women, which have practical implications for the fact that women are often not taken into account in literary criticism. Then, gynocritic criticism aims to find differences between men's and women's writing. This criticism specifically examines women writers. This criticism was developed in several aspects such as the history of women's literary works, writing style, themes, genres, and the structure of women's writing. Furthermore, socialist criticism, which is also called Marxist criticism. This criticism is used to see female characters in literature through a socialist perspective, namely based on the classes in the social structure of society. Next, psychoanalytic criticism is applied to various literary works written by women writers and it is considered that what is written is a psychological reflection of the writer. Then, ethnic criticism is applied to see how literary works perceive ethnic

39 Soenarjati Djajanegara, Kritik sastra feminis: sebuah pengantar (Jakarta: Gramedia Pustaka Utama, 2003), 20-21.

${ }^{40}$ Hasan Hanafi, Oksidentalisme: Sikap Kita Terhadap Tradisi Barat, Terj. M. Najib Buchori (Jakarta: Paramadina, 2000), 3. 
differences which have practical implications for gender inequality. Finally, lesbian criticism is literary criticism used by feminists in researching literary works written by lesbian groups with all the hidden messages in literary works. They use implied messages because they have been criticized by many parties, including feminist groups themselves. $^{41}$

The various models of feminist literary criticism above have become alternatives in an effort to transform the concept of gender recorded in the text into reality, which in this case is social life which is still tinged with a patriarchal culture that is still dominant with gender injustice.

\section{Gender mainstreaming in Arabic Literature: Perspective of Feminist Arabic Literary Criticism}

The birth of various Arabic literary works of various kinds cannot of course be considered as a separate text from the reality that surrounds them. Referring to the hermeneutic theory that is identical to the study of texts, a literary text in the hermeneutic locus of intentionalism is a text that has a meaning in accordance with what is immanent with the author's intention when writing the literary work, on the other hand a literary text in the Gadamerian hermeneutic locus is a text that has the appropriate meaning, with what is immanent with the reader's understanding when perceiving a literary work. These two poles of hermeneutics indicate that Arabic literature as a means of transforming gender mainstreaming through feminist Arabic literary criticism is a text that is always active in dialectic with space and time trajectories. An understanding of gender issues in Arabic literature as a basis for gender mainstreaming must be understood from the things that encourage a writer to convey these various gender issues through his Arabic literary work or from the point of view used by us as readers in transforming gender issues that are expressed or implied in various Arabic literary works as a basis for gender mainstreaming.

The illustration above is in line with what Diana Laurenson and Alan Swingewood stated that the existence of a literary work is a record of the social reality that surrounds it. As a consequence, by reading literary works, readers can understand various aspects such as events, forms, and content contained in the work. In addition, a

\footnotetext{
${ }^{41}$ Djajanegara, Kritik sastra feminis, 28-36.
} 
literary work can also reflect the reflection of the author who underlies the creation of the literary work. $^{42}$

In Arabic literature, gender is as a study that looks at how men and women share roles in the domestic and public sphere proportionally has signalled the gender mainstreaming as in Arabic literature by Najib al-Kilany entitled "Malikah al-'Inab". What Najib al-Kilany did in his work depicts a portrait of the life of women in Egypt at meetings between the late $80 \mathrm{~s}$ and early $90 \mathrm{~s}$ who have gained access to carry out activities in public spaces, including businesses that have been dominated by men. In the novel, Najib al-Kilany raised a female character named Bara'im as a female figure who has access to a gender-just life by becoming a successful businessman. Bara'im's success in her business was also supported by the heightened social solidarity he had as described by Najib al-Kilany as follows:

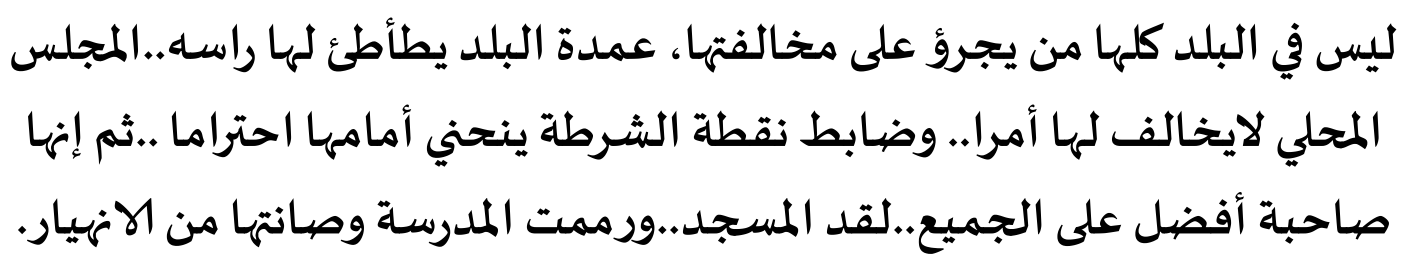

No one in this village dared to oppose her. The headman of the village bowed his head in front of her. The local council did not go against her orders. The police officer bowed in front of her as a form of respect. Then, she was also the kindest woman to everyone. She built a mosque, repaired the school and saved it. ${ }^{43}$

What Najib al-Kilany has done is form of Arabic literature that conveys strong gender mainstreaming messages. In the feminist Arab literary criticism that is socialist, it can be seen that the Bara'im character, who is described as a successful businesswoman, is able to convey a message to readers that women are able to go beyond the limits of their achievements that have been trapped in a patriarchal culture so that they can improve their position in the social level. They were previously only subordinate to men but there are times when they can also become leaders over men. Women who have been seen as the person who always waiting for instructions and orders from men in carrying out activities in public spaces are also able to carry out various negotiations on their own that require a high level of rationality. This indirectly supports the criticism that has been conveyed by Stephanie A. Shieds regarding the stereotype that women are creatures that

42 Diana Laurenson and Alan Swingewood, The Sociology of Literature (London: Collier MacMillan Publisher, 1972), 91.

${ }^{43}$ Najib Al-Kailany, Malikah Al- 'Inab (Kairo: Maktabah al-Mukhtar, 2008), 8. 
tend to be dominated by their feelings while men are rational creatures in their statement as follows:

It is public acceptance of the belief that "women are emotional, men are rational," the issues has not been studied empirically by contemporary feminist psychologist. It is just recognized as natural law; scientifically it remains untested. ${ }^{44}$

Stephanie A. Shieds argument shows that the immanent stereotype of men as rational beings while women are considered as emotional beings is only an assumption that is far from the socio-empirical facts. One of the efforts made by Najib al-Kilany as a step towards gender mainstreaming in his work is to raise one of the leadership characteristics inherent in the figure of Bara'im in conducting various trade negotiations. This is illustrated in one part of the novel "Malikah al-'Inab" by Najib al-Kilany as follows:

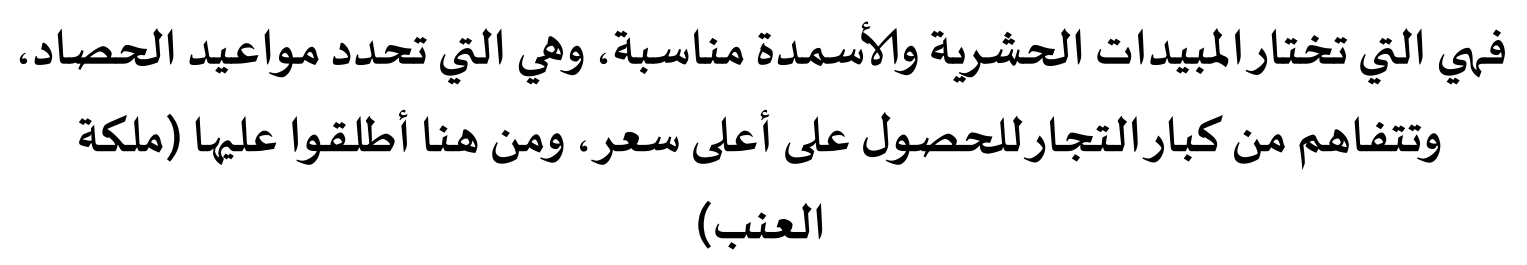

So she herself chose the suitable pest control and fertilizers, and she also limited the crop agreement. She also made deals with wholesalers to achieve the highest selling price that the people called her (Queen of Grape). ${ }^{45}$

In feminist Arabic literary criticism, what is experienced by the figure of Bara'im as a woman who got success after getting the opportunity to carry out various commercial activities in the public space needs to become a foothold in gender mainstreaming. As a consequence, the gender values contained in the story line of the novel "Malikah al-'Inab" by Najib al-Kilany need to be strengthened in the study of Arabic literature. This is where the power of literature as a work in which immanent many moral messages may be rejected if it is directly stated rather than the implied moral messages in the story line.

Another interesting Arabic literary work to serve as a reference in gender mainstreaming is the novel Banat al-Riyadh by Raja Abd. Allah al-Tsani who describes the figure of Qamrah who has three female friends, namely Michelle, Lumeis, and Sadeem. Four of them have several dreams related to the social reality that surrounds

\footnotetext{
${ }^{44}$ Stephanie A Shields, "Woman, Man, and the Dilemma of Emotion," in Sex and Gender, Phillip Shaver and Clyde Hendrick (ed). (London: Sage Publications, 1987), 231.

${ }^{45}$ Al-Kailany, Malikah Al-'Inab, 9.
} 
them with a strong patriarchal cultural style. One of the points in the novel that gives a strong gender message is when Michelle's mother had a disease and could not give birth anymore. In this condition, Michelle's mother, who should have taken care, heard sad news to allow her husband remarry with a reason that her illness made it impossible for her to give birth anymore. This is illustrated in the excerpt from the story in the novel Banat al-Riyadh by Raja Abd. Allah al-Tsani as follows:

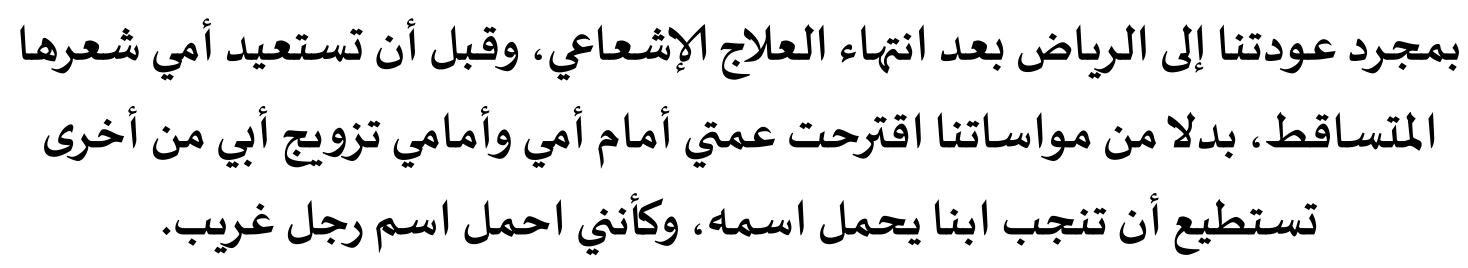

As soon as we returned to Riyadh after undergoing chemotherapy treatment and before my mother noticed her hair loss, instead of cheering us up, my aunt suggested my father that he should marry another woman who would enhance his reputation in front of my mother and in front of myself, as if I was enhancing the reputation of a stranger. ${ }^{46}$

What happened to Michelle's mother in the excerpt from the novel of Banat alRiyadh by Raja Abd. Allah al-Tsani shows a form of gender injustice in women's life that makes Riyadh, Saudi Arabia as the background. In the novel, it is illustrated how a woman is nothing more than a place for a man who happens to be her husband to expect the birth of a child. Consequently, a wife's inability to give him offspring is seen as a reason for a husband to remarry.

Moreover, in the excerpt from the novel's story, it is described that the one who gave the suggestion for Michelle's father to get married was her own aunt who was also a woman. Empathy among women was no longer visible in Arab society when dealing with beliefs that have been influenced by this patriarchal culture. In addition, the existence of Michelle as a daughter was seen as insufficient to enhance his reputation of her father and her extended family so that her father was advised to remarry so that he could have a child. The lack of respect for women is a form of gender injustice that afflicts women in various parts of the world. This was emphasized again by King Abd. Allah al-Tsāni through his quote on the poem of Nizar Qobbani as follows:

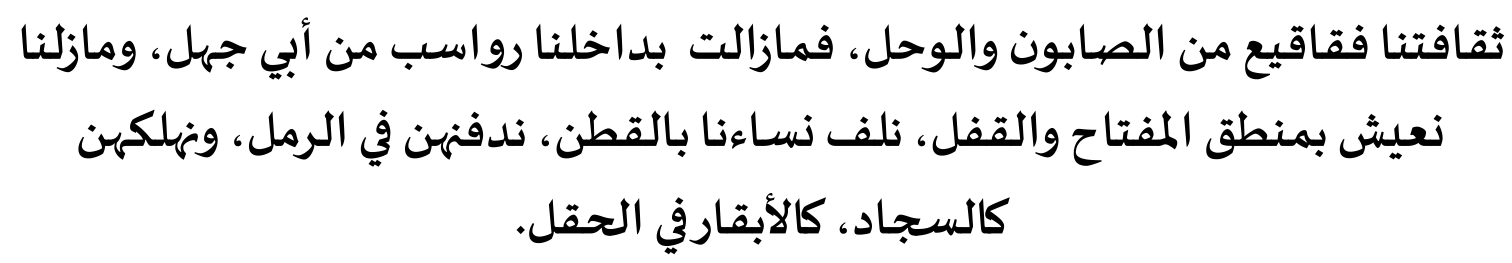

${ }^{46}$ Raja Abd. Allah al-Tsani, Banat Al-Riyadh (Beirut: Dar al-Tsaqi, 2006), 105. 
Our culture is like soap foam and mud bubbles. The remains of Abu Jahl are still in us. We still live by the logic of keys and locks. We cover our wives with clothes. We bury them in the sand. We destroy them like a carpet, like cows in the fields, we go to them at the midnight. ${ }^{47}$

The use of various metaphorical expressions above illustrates how women's selfesteem is considered very low in Arab society. As the effort, gender mainstreaming in Arabic literature through feminist Arabic literary criticism, various gender issues must be transformed from text to reality. Literature which was written by women such as Nawal Sa'dawi, al-Khanza, and others, women's roles in Arabic literature such as Bara'im in Malikah al-'Inab by Najib al-Kilany, Michelle in Banat al-Riyadh by King Abd. Allah alTsani, and others, or the messages that full of gender issues that are immanent in the Arabic literature is a means of gender mainstreaming. In its implementation, these various gender issues are transformed in a variety of different spaces of time. After these values have been transformed in various time spaces with various gender problems that they experienced such as marginalization of women, subordination of women to men, violence, negative stereotypes, and others, gender mainstreaming implies the need for reconstruction of gender relations that are responsive to women's rights which has been dominated by men.

Feminist Arabic literature criticism can be a platform in reconstructing these gender relations which various feminist literary criticism theories such as ideological criticism, gynocritic criticism, socialist criticism, psychoanalytic criticism, ethnic criticism, and lesbian criticism are used as weltanschauung in understanding various gender relations in Arabic literature, either constructive or destructive. Mainstreaming gender in Arabic literature does not only involve feminist Arabic literary criticism as a perspective that assesses whether or not a literary work is good or bad but also seeks to see how the criticism can transform gender issues as well as reconstruct gender relations between men and women that are more responsive about gender.

\section{Conclusion}

Gender mainstreaming in Arabic literature through feminist Arabic literary criticism is a structured step in transforming text into reality. The use of Arabic literature as a platform for gender mainstreaming is seen as the right choice considering that Arab society based on their historical traces has stereotypes with its patriarchal culture. As a

${ }^{47}$ Ibid, 32.
259 | Jurnal AilBayan: Jurnal Jurusan Pendidikan Bahasa Arab, 12 (2): 245-262 (2020) 
consequence, the social conditions that are less responsive about gender have influenced the birth of Arabic literary works of various kinds. Through feminist Arabic literary criticism with its various critical theories such as ideological criticism, gynocritical criticism, socialist criticism, psychoanalytic criticism, ethnic criticism, and lesbian criticism, Arabic literature has become a attractive alternative for gender mainstreaming. The use of Arabic literature based on feminist Arabic literary criticism in an effort to gender mainstreaming is one of the best choices to transform and reconstruct the relations between men and women which are more gender-responsive.

\section{Acknowledgment}

The authors would like to express gratitude to Universitas Islam Negeri Alauddin Makassar, Indonesia especially Arabic Education Study Program, for supporting this research.

\section{References}

Al-Kailany, Najib. Malikah Al-'Inab. Kairo: Maktabah al-Mukhtar, 2008.

Almandary, Haeruddin. "Karakteristik Sastra Arab pada Masa Pra-Islam.” Nady Al-Adab 13, no. 1 (January 23, 2018): 35-50.

Aramendia-Muneta, Maria Elena, Cristina Olarte-Pascual, and Leonidas Hatzithomas. "Gender Stereotypes in Original Digital Video Advertising." Journal of Gender Studies 29, no. 4 (May 18, 2020): 403-419.

Aziz, Abd, and M. Imam Sofyan Yahya. "Kritik Intrinsikalitas dan Ekstrinsikalitas Sastra Modern dalam Kajian Sastra Arab Modern." Mumtaz: Jurnal Studi Al-Quran dan Keislaman 3, no. 1 (October 21, 2019): 23-36.

Djajanegara, Soenarjati. Kritik sastra feminis: sebuah pengantar. Jakarta: Gramedia Pustaka Utama, 2003.

Elomäki, Anna, and Paula Koskinen Sandberg. "Feminist Perspectives on the Economy within Transforming Nordic Welfare States." NORA - Nordic Journal of Feminist and Gender Research 28, no. 2 (April 2, 2020): 81-85.

Eriyanti, Linda Dwi. "Pemikiran Johan Galtung tentang Kekerasan dalam Perspektif Feminisme.” Jurnal Hubungan Internasional 6, no. 1 (January 17, 2018): 27-37.

al-Faishal, Abd. al-Aziz bin Muhammad. Al-Adab al- 'Arabi Wa Tarikhuhu. Riyadh: : alMamlakah al-'Arabiyah al-Su'udiyyah, 1405.

Fakih, Mansour. Analisis gender dan transformasi sosial. Pustaka Pelajar, 2013.

Gartung, Johan. "Local Authorities as Peace Factors/Actors/ Workers." Journal of World-Systems Research (November 26, 2000): 860-872. 
Hammad, Hanan. "In the Shadows of the Middle East's Wars, Oil, and Peace: The Construction of Female Desires and Lesbianism in Middlebrow Egyptian Literature." Journal of Arabic Literature 50, no. 2 (July 15, 2019): 148-172.

Hanafi, Hasan. Oksidentalisme: Sikap Kita Terhadap Tradisi Barat, Terj. M. Najib Buchori. Jakarta: Paramadina, 2000.

Hartman, Michelle. "Zahra's Uncle, or Where Are Men in Women's War Stories?" Journal of Arabic Literature 51, no. 1-2 (April 6, 2020): 83-107.

Husain, Al-Ziyat Ahmad Husain. Tarikh Al-Adab al-Arabi. Kairo: Dar al-Ma'rifah, 1975.

Iskandari, Ahmad, and Mustafa Inani. Al-Wasith Fi al-Adab al-'Arabi Wa Tarikhihi. Kairo: Dar al-Ma'arif, 1916.

Jatiningsih, Oktiana. "Pengarusutamaan Gender (PUG) Dalam Pendidikan Sebagai Strategi Pendidikan Karakter Bagi Calon Guru Di Lembaga Pendidikan Guru Dan Tenaga Kependidikan." Prosiding Seminar Nasional Lembaga Pengembangan, Pembelajaran, dan Penjaminan Mutu (November 5, 2016).

Jones, Edward Harrell. Outlines of Literature; Short Stories, Novels, and Poems. New York: Macmillan, 1968.

Knutson, Douglas, Julie M. Koch, Jenilee Sneed, Anthony Lee, and Mar Chung. "An Exploration of Gender from The Perspective of Cisgender Male Drag Queens." Journal of Gender Studies 29, no. 3 (April 2, 2020): 325-337.

Kusumawati, Aning Ayu. "Feminisme Islam dalam Novel Abidah El Khalieqy." THAQAFIYYAT: Jurnal Bahasa, Peradaban dan Informasi Islam 14, no. 2 (2013): 115-137.

Laurenson, Diana, and Alan Swingewood. The Sociology of Literature. London: Collier MacMillan Publisher, 1972.

Maryam, Sitti. "Historisitas Aliran Neo-Klasik Dalam Kesusastraan Arab." Al-Irfan: Journal of Arabic Literature and Islamic Studies 2, no. 1 (March 30, 2019): 121141.

Mufidah. Pengarusutamaan Gender Pada Basis Keagamaan: Pendekatan Islam, Strukturasi, Dan Konstruksi Sosial. Malang: UIN Malang Press, 2009.

Musgamy, Awaliyah. "Menakar Batas Kesetaraan Gender Poligami Dalam Pp. No. 45 Tahun 1990 Tentang Izin Perkawinan Dan Perceraian Bagi PNS." Al Daulah: Jurnal Hukum Pidana dan Ketatanegaraan 6, no. 2 (June 25, 2018): 395-404.

Muzakki, Akhmad. "Karya Sastra: Mimesis, Realitas Atau Mitos?" LiNGUA: Jurnal Ilmu Bahasa dan Sastra 2, no. 1 (October 13, 2011): 26-44.

Kesusastraan Arab Pengantar Teori Dan Terapan. Jakarta: ANS, 1995.

Nasir, Amin. "Bahasa Arab Era Klasik Dan Modern (Tinjauan Pembelajaran Teoritis)." Arabia 6, no. 1 (2014). Accessed June 27, 2020. https://journal.iainkudus.ac.id/index.php/Arabia/article/view/1393.

Ne'Eman-Haviv, Vered. "Attitudes of Arab Israeli Students towards Honour Killings." Journal of Gender Studies (June 2, 2020): 1-11. 
Nuroniyah, Wardah. "Perempuan Arabia Dalam Lingkaran Perkawinan Di Era PraIslam." Yinyang: Jurnal Studi Islam Gender dan Anak 14, no. 2 (December 10, 2019): 175-200.

Patel, Ismail Adam. Perempuan, Feminisme Dan Islam, Terj. Abu Faiz. Bogor: Pustaka Thariqul Izzah, 2005.

Reinharz, Shulamit. Metode-Metode Feminis Dalam Penelitian Sosial, Terj. Lisabona Dan J. Bambang Agung. Jakarta: Women Research Institute, 2005.

Ritonga, Deffi Syahfitri. "Kajian Gender Pada Novel Karya Nawal El Saadawi Dan Sutan Takdir Alisjahbana." Arabiyat: Jurnal Pendidikan Bahasa Arab dan Kebahasaaraban 3, no. 1 (June 28, 2016): 13-31.

Rusydi, Muhammad. "Esoterisme Pemikiran Gender Nasaruddin Umar." AN-NISA : Jurnal Studi Gender dan Anak 12, no. 2 (March 10, 2020): 710-716.

Saryono. Pengantar Apresiasi Sastra. Malang: Universitas Negeri malang, 2009.

Shields, Stephanie A. "Woman, Man, and the Dilemma of Emotion." In Sex and Gender. Phillip Shaver and Clyde Hendrick (ed). London: Sage Publications, 1987.

Sugihastuti, and Suharto. Kritik Sastra Feminis: Teori Dan Aplikasinya. Yogyakarta: Pustaka Pelajar, 2002.

Sumar, Warni Tune. "Implementasi Kesetaraan Gender dalam Bidang Pendidikan." MUSAWA 7, no. 1 (June 2015): 158-182.

Sumarjo, Jacob, and Saini. Apresiasi Kesusasteraan. Jakarta: Gramedia Pustaka Utama, 1997.

Tedjomukti, Ratna Ajeng, and Agung Sasongko. "Sastra Arab dari Berbagai Zaman." Republika Online. Last modified August 15, 2017. Accessed June 27, 2020. https://republika.co.id/share/ouoyap313.

al-Tsani, Raja Abd. Allah. Banat Al-Riyadh. Beirut: Dar al-Tsaqi, 2006.

"Instruksi Presiden Nomor 9 Tahun 2000 Tentang Pengarusutamaan Gender Dalam Pembangunan Nasional." Republik Indonesia, n.d. Accessed April 14, 2020. https://www.kemenkeu.go.id/sites/default/files/inpres-no.-9-tahun-2000-tentangpug.pdf. 